\title{
An action research project aimed at raising social consciousness amongst women attending transactional analysis group psychotherapy in Brazil
}

\author{
(C) 2015 Jane Maria Pancinha Costa
}

\begin{abstract}
Based on awareness of material by Gramsci (1978, 1982) on hegemony, Freire $(1979 a, 1979 b)$ on cooperative contact, and Steiner (1975) on radical psychiatry, action research methodology was used by the researcher, who was also a psychotherapist, with 12 women attending two ongoing weekly psychotherapy groups in Brazil in order to raise their social consciousness of culturally-based oppression of women, particularly relating to work; to apply life script analysis as a therapeutic intervention within the groups; and to facilitate recognition by the women of the benefits of cooperative contact when seeking to liberate themselves from oppression. Individual structured interviews were conducted and the data from these was discussed within the groups, leading to the development of a model containing 6 levels of consciousness of oppression. Examples of oppression identified by the women are provided, with only $17 \%$ relating directly to sexual discrimination at work. Although the research was conducted many years ago (1987-1989), it is shown that problems still exist and the research methodology could usefully be applied elsewhere.
\end{abstract}

\section{Key words}

hegemony, social consciousness, discrimination, transactional analysis, group psychotherapy, action research, radical psychiatry, levels of oppression

\section{Introduction}

This research developed from practice as group psychotherapist in Brazil with two groups of women, from different socio economic and cultural contexts, over two years of group meetings for two hours weekly. Questions emerged in the groups about social or external constraints and intrapsychic or internal constraints experienced by the women. I started to ask myself questions: if we consider that relationships are permeated by ideologies that become embedded in individuals, and if the elements of the internal processes in individuals can be understood and known through transactional analysis theory, particularly life script (Berne, 1974; Steiner 1976), how can these elements contribute, in a joint reflection, to enlarge and expand the spaces of perception and action by women? How can they contribute to help women develops critical awareness about their role in society as individuals, a gender and a part of the whole?

The research was conducted through a qualitative methodology using action research of an awarenessraising character. The objective of the therapy was to raise the awareness and action capacity of the group members through the flow of awareness raising plus the contact with other women. The objective of the research was to identify the ways in which the women were being limited by society and were limiting themselves, so that they could better identify appropriate behaviour changes.

\section{Theory Review}

\section{Radical Psychiatry}

According to the Radical Psychiatry approach, an individual needs the support of a group of other human beings in order to move against aggression. Steiner (1975), proposed that “... in the absence of oppression, human beings will, due to their basic nature or soul, which is preservative of themselves and their species, live in harmony with nature and each other. Oppression is the coercion of human beings by force or threats of force, and is the source of all human alienation.

Alienation is the essence of all psychiatric conditions.

All alienation is the result of oppression about which the oppressed has been mystified or deceived" ( $p$. 10).

Oppression is often supported by laws and traditions. In interpersonal relationships, oppression consists of taking away from someone, by force or threats, physical or psychological manipulation, something that belongs to those individuals, and which they do 
not want to give away, and which otherwise they would not give away.

Another important aspect is that mystifications, or lies, constitute a powerful method to destroy people's ability to understand the world and to be effective. These lies pave the way for submission, obedience and the belief that failure and unhappiness are exclusive products of one's own guilt. Obedience and the acceptance of mystifications are taught in many childhood institutions, as we learn to do what we are told.

Each oppressive system has a series of mystifications that justify the abuse of power perpetrated over its victims, so that those who are oppressed come to believe in the lies used to justify oppression. When arguments that explain and legitimize oppression have been incorporated into someone's awareness, mystification and alienation are complete. Thus, people will no longer rebel against oppression, but will blame themselves instead. They will accept and admit that they are the source of and reason for their own unhappiness. They will apply their internalized oppression to those around them and will reinforce oppression of others through their own oppression. Alienation characterizes itself as a person's feeling of being apart from the main group. According to Steiner et al (1975), alienation does not refer to the separation of an individual from other people, but rather, to an individual's isolation in relation to themself, from their human possibilities of work, of thought, of love. It refers to the separation of an individual from their body, always as a result of the deluded acceptance of oppression.

When people are alienated from their job and fragmented, they isolate themselves from other people and force themselves to be competitive, becoming alienated from other people, too. This alienation is supported by the belief in individualism and competition as a means of acquiring assurance in the fulfillment of needs and happiness. Hence, according to radical psychiatry, two factors are necessary for liberation: awareness of oppression including the sources of it, and cooperative contact with other human beings who, united, will move against the oppression through some form of action.

\section{Society}

For the transformation processes that are the subject of this study, there needed to be a change in the awareness of the individual women in their everyday relations, so it became necessary to deepen the comprehension of the dialectic relationship and reciprocal action (organic bond) between society's structure and superstructure. For this, Gramsci's $(1978,1982)$ material is relevant, as even authors who disagree with many of his ideas (Strinatti 1995) are unanimous in asserting the importance of his work to the understanding of the historical block (Baratta 2001). Gramsci wrote of structure as the set of productive action material forces. In a global historical situation (historic block), it is the less variable element, in which each change may be verified and measured with mathematical accuracy. The structure is justly shifted to reality because it is the testimony, the incontestable document of what has been done, and it continues to subsist as the condition of present and future. (Portelli, 1983).

The superstructures of the historic block form a complex set in which two spheres are distinguished as two elements: the Political Society and the Civil Society. The first has well-defined features; it gathers the set of superstructure activities that concern the coercion function. In that sense, it is an extension of the Civil Society. Gramsci often defines the State as the Civil Society plus the Political Society i.e. armored coercion hegemony, or the State in its integral meaning of dictatorship plus hegemony. The Civil Society is an intermediary sphere that includes aspects of structure and superstructure, and is a complex set that gathers every organism said to be private and through which the hegemony function, exerted all over society by the dominant group, is expressed.

Hegemony may be considered under three complementary aspects:

1. as the ideology of the governing class, it reaches every field of ideology, all the way from art to science, including economics, law, etc.

2. as a conception of the world, diffused through all social layers to link them to the governing class, that adapts itself to all groups. From this adaptation come different qualitative degrees of philosophy, religion, common sense and folklore.

3. as society's ideological direction, it articulates itself on three levels: ideology itself, the ideological structure (organisations that create and diffuse the ideology, as well as all means of communication and the cultural ones that may allow influence on the public opinion) and the ideological material (technical instruments for diffusing the ideology). Gramsci defines ideology as "a conception of the world that implicitly manifests itself in art, law, economical activity, in every individual and collective life manifestations." (Portelli, 1983, p. 23)

Ideology, governing class conception of the world, must diffuse itself throughout society. Thus, it is not homogenous in all levels: the ideology diffused on each governing layer is more elaborate than its fragments found in popular culture. 
Civil Society's domination expresses itself in the form of hegemony, and every hegemonic relationship is necessarily a pedagogical relation. The domination of consciences, through the practice of hegemony, is an indispensable element to stabilize a relationship of domination and, with that, the relationship of production. It is in that context that the conception of Civil Society as a place of diffusion of ideologies takes on importance.

Gramsci refers to individuals as intellectuals, contributing to the evaluation of the importance of individual change in the reading of the world, for the superstructure modification in the core of Civil Society. However, according to Freire (1979a) "The alienated society has no awareness of its own existence... The alienated being does not look at reality with personal criterion, but through other people eye's." (p. 35)

\section{Cooperative Contact}

According to Freire (1979b), an individual cannot think without the co-participation of other individuals in the act of thinking. True dialogue, however, is not possible if the people involved do not commit themselves to critical thinking, through which reality is perceived as a process of evolution and transformation. The development of awareness is more than just becoming aware of something. It involves, "the critical insertion of the person with a developed awareness in a demystified reality." (p.90). Such cooperative contact needs to be practiced and the awareness of it developed and watched over, since it is not spontaneous at first. Being spontaneous in a society that is built on exploitation goes against common sense when relationships are based on individualism and competition.

The training for power and psychological games is quite massive, since the games are part of hegemony. When they happen, they have to be resolved by friendly confrontation, negotiation and contracts. Among people who are committed to self transformation and the transformation of others, this confrontation becomes especially possible when there is awareness of the determining role of the games for the maintenance of hegemony.

In the same way, the search for cooperative contact among people who feel oppressed requires an awareness of oppression which is the second level of awareness. With this second level present, contact, if established on a cooperative basis, makes de-alienation easier at the remaining levels. This moves people closer to liberating action. The contact on a cooperative basis is necessary to produce, create, transform and not just reproduce the status quo. This is a way of taking possession of one's self, a way of breaking free from alienated forms of thinking, feeling, and behaving in the intra and interpersonal relationships, acting to disclose and transform hegemonic oppression and inequality.

Transactional Analysis

Since the original study was undertaken many years ago, a great deal more relevant transactional analysis material has been published to add to that available at the time of the study and some of that has now been included here.

Levin (1977), discussing women's oppression, pointed out that that gender roles hurt both men and women, and that cultural values that regarded the roles of women as inferior to those held by men were reinforced through the practices of parenting, social influences and psychiatry theory. Later, Levin (2010) challenged that the same scenarios still exist, and commented that the 'inferiority' is particularly evident in leadership positions.

James (1983), addressed cultural scripts and social change, considered the family as a small subculture but pointed out that political parties, religion, socioeconomic and racial groups, including professional associations, can influence as much as parents do. She wrote that the down-scripting of women in all cultures and all times is a clear example of the "collective ego states of a world-wide cultural belief that women should be kept down as that is their "place", to be subordinate - no matter what. A massive worldwide cultural contamination in both men and women, these contaminations are continued today." (p.220).

Drego $(2006,2009)$ emphasised the power of social transformation of transactional analysis. Both Levin (1977) and Drego (2006) refer to Steiner (1975) and radical psychiatry as a forerunner in the advancement of the social aspects of transactional analysis. Drego (2006), referring to collective action that leads to social change, quotes from Kabeer (1994) "We have stressed...the importance of incorporating women's own needs and priorities into the construction of organizational agendas ...Strategies of empowerment from within provide women with these other perspectives. They entail reflection, analysis and assessment of what has hitherto been taken for granted so as to uncover the socially constructed and socially shared basis of apparently individual problems. New forms of consciousness arise out of women's newly acquired access to the intangible resources of analytical skills, social networks, organisational strength and sense of not being alone. (pp. 245-246 in Drego, p. 102)

Mazzetti (2010) refers to Reisman's (1950) analysis of the development of human society, and how third phase societies, with stable democracies as is 
common in advanced capitalist societies, have a social character that is "other-directed" in that individuals respond behaviourally to peers rather than tradition. The winner's stereotypes within these cultures are therefore reinforced by the environment, and sometimes through counsellors and psychotherapists who are unaware that they are colluding. Mazzetti suggests that, in order to deal with our cultural scripts, we need to pay attention to "[how] the cultural script usually creates fewer social difficulties than other aspects of a person's script because it is consistent with the expectations of the sociocultural environment. This can make diagnosis more difficult. ... The therapist may be unaware of being contaminated by sociocultural prejudices. ... Cultural script behaviors, which are reinforced by the environment, become even more powerful because most people share them, and they are constantly displayed in the media, marketing, and so on." ( $p$. 193)

Campos (2012) refers to how individuals also gain strength at a collective level from positive connections with others and maintains that the heart of transactional analysis is in helping people develop the courage to risk positive change, not only at the individual level but also at the collective cultural level.

As part of forming their life script, people take on and develop basic beliefs and feelings about themselves and others that might structure a lifetime as opposed to autonomy. Using this theory, it becomes possible to begin to understand in what way - at the intrapersonal level - the phenomenon that is described by Gramsci (1982) happens such that "In the consciousness of children, "what is right" becomes "what is true". But a child's consciousness is not an individual (let alone individualized) thing. It is rather the reflex of that portion of the Civil Society in which he/she participates, the social relations as they are found in the family, in the neighborhood, village, and so on." (p.131)

In Berne's (1974) words "Although human beings are not laboratory animals, they often behave as such. Sometimes they are put in cages and treated like rats, manipulated, and put to sleep, according to their masters' will. Cages often have an open door, and one has but to leave, if he or she wants to. If they do not do so, it is because as a rule their Script keeps them there." (p.71)

Life script is, in dialectical terms, a strategy for survival (it is so mainly during childhood) and, at the same time, it is the anti-life mechanism that needs to be overcome. So it is characterized as an alienated life plan which was decided for - under pressure during childhood. Part of it contributes to maintaining consensus in a society marked by the exploitation of the majority by a minority of the population. Therefore, when analyzed in the light of people's place in society, script theory can be a way of understanding an individual's contradictions in everyday life.

When we think of women, there are many evidences about the influences of socioeconomic and cultural patterns, including on women's work. The so-called feminine characteristics (values, desires, behaviours) are undertaken by means of a complex individual and asocial process of gender acquisition. The masculine-feminine dichotomy establishes generally rigid stereotypes. These stereotypes limit the roles, and limit people's possibilities by encouraging or repressing behaviors according to whether or not they are appropriate to the gender. The structure of gender eventually is converted into such a powerful social fact that it is often thought to be natural.

The different socio-biological interpretations fall into the gender categories. Thus, even if there are variations related to culture, social class, ethnic group and even generations, it is possible to recognize a basic division corresponding to the most primitive work-related sexual division. Women have their children and therefore take care of them. Feminine means maternal, domestic; it is the opposite of the masculine characteristics, which are public. The gender categorisation, therefore, makes it possible to indicate with greater clarity and precision how difference promotes inequality. This segment of society - woman - can be considered so specific because, although there are differences in behavior and in the kind of oppression to which women are subject (since they are from different social classes) there are a few elements which are constants. They are constants both in what is expected of women and in where they locate themselves. Women from different classes have differences and also a lot of converging elements.

Educational institutions, in turn, instead of encouraging women to attempt new activities and new areas, seem to reinforce and stimulate even more the traditional role. In pre-school, boys and girls find the ratification of the social panorama and the demarcation of masculine and feminine roles. This happens because, in the environment in which they are taken care of, most of the time men feel absent. And like a mother's, a teacher's work is also not seen as a job or profession in the plain sense of the word, but as a job, more or less authoritative, more or less benevolent and not worth much payment.

In relation to children's literature, many papers and books that make the sexual discrimination clear are 
used in schools. In Brazilian textbooks, according to data gathered by Nosella (1981), the mother is mentioned as a family member who usually does not work, but takes care of the home, the husband and the children. Their social role is reduced to wife, mother and housewife, and presented as uninformed and ignorant. When occupying any position, it is in typically feminine professions, generally socially, economically and culturally devalued (Toledo et al, 1983). Men, on the contrary, are the informed ones, they read the paper, and are undeniably superior. In textbooks, mothers are never seen as human beings that have the need for personal and social achievement. The only profession that can be exercised by them is that of a teacher, seen as a complementary profession for the performance of her motherly duties.

Invariably, in the analysed readings, a mother is a symbol of love, sacrifice, protection and holiness. Nosella emphasizes the fact that "stereotype" mothers do not belong to a defined social class, not indicating at all that some are rich and others not quite so; they transcend the class concept.

To Wyckoff (1976), at a script level women in the modern capitalist society are programmed to be the complementary half of the productive man. "As men and women, we're socialized in the sense of developing certain parts of our personalities, while suppressing the development of others. This programming promotes a pre-determined, repetitive, and artificial way of acting... In a classic way, a man "should be" rational, productive, and hardworking, but he "shouldn't be" emotive, in touch with his feelings, and openly loving. On the other hand, a woman "shouldn't" think rationally, be able to do the accounting or be strong. (p. 160)

\section{Research Questions}

The research questions for this action research study were framed as:

1. Is it possible to identify the sources of instances of oppression that are reported by the women in the study?

2. Will the sources of oppression vary between different socio economic classes?

3. Can we link those sources of oppression that appear to be internally generated to the transactional analysis theory of life scripts?

4. Is it possible to use life script analysis as a therapeutic intervention within a group psychotherapeutic work in order to help the women understand and overcome sources of oppression?

\section{Methodology}

\section{Action Research}

The research approach was of action research, which Koshy et al (2011) describe as commonly used for improving conditions and practices, Parkin (2009) suggests is to bring about change in specific contexts, and Meyer (2000) proposes to be an approach which can generate solutions to problems and empower practitioners. Those authors appear to concentrate on the practitioner improving their own practice, whereas in this current study the focus was on using the results to empower the participants. This focus is summed up by action researcher Swantz (2001) when commenting that "For me it is really a quest for life, to understand life and to create what I call living knowledge - knowledge which is valid for the people with whom I work and for myself." (p.1)

Whyte (1991) explains how what he calls Participatory Action Research involves the practitioner in the research process through from the initial design of the project through data gathering and analysis to final conclusions and actions arising out of the research. For this study, this translates into an initial design for conducting structured interviews (see Appendix 1 for the questions used) with the members of two ongoing therapy groups, the analysis of the interview data, and the subsequent development within the groups of a model for classifying the data from the participants, the application of transactional analysis concepts to participants' issues in order to facilitate the identification of potential behaviour changes, and the ongoing facilitation of the implementation of such changes.

\section{Ethical Considerations}

This study was conducted under the auspices of the Faculty of Education of the Federal University of Rio Grande do Sul.

All participants agreed to be involved in the action research process, which of course was implemented through the psychotherapy groups that they were attending. It was made clear to them that refusing to join the research would not mean that they were no longer allowed to be in the group.

They agreed to attend the research interviews and gave permission for the interviews and group work to be recorded. They also gave permission to the author to write about the work, and contributed their own material for inclusion. The researcher promised that all material would be made anonymous and kept confidential. 
A significant ethical consideration was the potential conflict of being the researcher whilst also being the psychotherapist. This is of course a common consideration when action research is the methodology. It was felt that, as the purpose of the research was to focus on empowering the participants, this would not conflict with the identical aim for the psychotherapy.

\section{The Groups}

The demographics of the two groups are shown in Table 1. This study was developed from the work with women's groups from different socio-economic and cultural levels. These were basically therapeutic groups, but also growth groups and workshops that had been running for about 10 years. The research took place from 1987 to 1989.

One group was composed in a public health centre of a peripheral village of Porto Alegre. The work in this village had been developed since 1978 through a project of Community Health initiated by a group of students from the Faculty of Medicine of the Federal University of Rio Grande do Sul in an extra-curricular activity in which the author was included (Pozatti, 1980). Some of the women participating in this group therapy had been working with students and professionals from various areas of the health centre, and had participated in activities such as taskforces, campaigns, organization of community associations, and development and promotion of a theatre group. Others came to the group about problems with 'nerves', medical indications or issues with neighbours. There were six women in the group, married, separated and widowed, with children, with and without current paid jobs and with varying levels of education within the first degree of formal education. They were in a low-level socioeconomic context.

\begin{tabular}{|c|c|c|c|c|c|c|c|c|}
\hline & Age & $\begin{array}{l}\text { Civic } \\
\text { status }\end{array}$ & $\begin{array}{c}\text { Educational } \\
\text { level }\end{array}$ & Origin & $\begin{array}{l}\text { Place of } \\
\text { Activity }\end{array}$ & $\begin{array}{l}\text { Family } \\
\text { income } \\
\text { (salary) }\end{array}$ & $\begin{array}{c}\text { When } \\
\text { begun } \\
\text { to earn } \\
\text { salary } \\
\text { (age) }\end{array}$ & Children \\
\hline \multicolumn{9}{|c|}{ Group 1} \\
\hline A & 36 & Married & $\begin{array}{l}\text { Alphabet } \\
\text { school }\end{array}$ & Rural & Home & $1 x$ & & 2 \\
\hline B & 34 & Widow & Primary & Rural & Trade & $2 x$ & 17 & 2 \\
\hline C & 49 & Widow & Primary & Urban & Home & $2 x$ & & 4 \\
\hline D & 47 & Married & Primary & Rural & $\begin{array}{l}\text { General } \\
\text { service }\end{array}$ & $3 x$ & 45 & 7 \\
\hline$E$ & 46 & Married & Primary & Rural & Home & $1 x$ & & 2 \\
\hline $\mathbf{F}$ & 47 & Separated & Primary & Rural & Creche & $2 x$ & 35 & 3 \\
\hline \multicolumn{9}{|c|}{ Group 2} \\
\hline G & 37 & Married & $\begin{array}{c}\text { Higher } \\
\text { education }\end{array}$ & Urban & Professional & $23 x$ & 25 & 3 \\
\hline $\mathbf{H}$ & 43 & Married & $5^{\text {th }}$ Grade & Urban & Trade & $24 x$ & 17 & 0 \\
\hline I & 28 & Married & $\begin{array}{l}\text { Higher } \\
\text { education }\end{array}$ & Urban & Professional & $40 x$ & 24 & 2 \\
\hline $\mathbf{J}$ & 37 & Married & $\begin{array}{c}\text { Higher } \\
\text { education }\end{array}$ & Urban & Professional & $45 x$ & 22 & 2 \\
\hline $\mathbf{L}$ & 31 & Married & $\begin{array}{c}\text { Higher } \\
\text { education }\end{array}$ & Urban & $\begin{array}{l}\text { Public } \\
\text { service }\end{array}$ & $24 x$ & 22 & 1 \\
\hline M & 32 & Married & $\begin{array}{l}\text { Higher } \\
\text { education }\end{array}$ & Urban & Professional & $45 x$ & 21 & 2 \\
\hline
\end{tabular}

Table 1: Characteristics of Groups 
The other group was composed in a private psychotherapy clinic in the urban area of Porto Alegre. This group began in August 1986. Some sought a specific space to work on individual questions related to their womanhood. Others were individual psychotherapy clients and were invited to participate in the therapeutic group. There were again 6 participants, married or single, with and without children, with and without current paid jobs and with varying levels of education, including university courses. These women were embedded in a mid-level socio-economic context, similar to that of the researcher.

\section{Results}

Situations identified as oppressive

Table 2 summarises the three top situations described by participants as oppressive.

\begin{tabular}{|c|c|c|c|}
\hline & 1st & 2nd & 3rd \\
\hline \multicolumn{4}{|c|}{ Group 1} \\
\hline A & $\begin{array}{l}\text { Too many clothes to wash } \\
\text { and someone comes }\end{array}$ & Going shopping & Illness in the family \\
\hline B & $\begin{array}{c}\text { Doing business (shopping, } \\
\text { taxes) }\end{array}$ & $\begin{array}{l}\text { Fear of assault on my } \\
\text { warehouse }\end{array}$ & Driving the car \\
\hline C & Arranging a house & Worrying about my children & Illness in the family \\
\hline D & Being criticised at work & My job as a cleaner & Working on Saturday \\
\hline $\mathbf{E}$ & $\begin{array}{l}\text { When I think that I will not } \\
\text { earn my money (fees) }\end{array}$ & $\begin{array}{l}\text { When my husband is at home } \\
\text { and I am working }\end{array}$ & When I have to lie \\
\hline $\mathbf{F}$ & Lack of money & Arguments & $\begin{array}{c}\text { When I want to do something } \\
\text { better in the community and it } \\
\text { does not work }\end{array}$ \\
\hline \multicolumn{4}{|c|}{ Group 2} \\
\hline G & Difficulties with colleagues & Feelings of inadequacy & $\begin{array}{l}\text { Difficulty of raising my } \\
\text { professional fees }\end{array}$ \\
\hline $\mathbf{H}$ & $\begin{array}{l}\text { Difficulties to understand } \\
\text { something }\end{array}$ & $\begin{array}{l}\text { Commit to a lot and cannot } \\
\text { complete }\end{array}$ & $\begin{array}{l}\text { When I need to justifying } \\
\text { something to someone else }\end{array}$ \\
\hline $\mathbf{I}$ & $\begin{array}{l}\text { When I spend too much to } \\
\text { work }\end{array}$ & $\begin{array}{l}\text { Difficulty of reconciling work, } \\
\text { home, kids }\end{array}$ & \\
\hline $\mathbf{J}$ & Husband commands & $\begin{array}{l}\text { My ideas are not valued at } \\
\text { work }\end{array}$ & $\begin{array}{c}\text { My ideas being used by } \\
\text { someone else as their own } \\
\text { (men) }\end{array}$ \\
\hline $\mathbf{L}$ & $\begin{array}{l}\text { When I need to solve } \\
\text { problems with authority } \\
\text { figures (boss) }\end{array}$ & Involved in conflicts at work & $\begin{array}{l}\text { The boss ask me to work } \\
\text { harder and I accept }\end{array}$ \\
\hline $\mathbf{M}$ & $\begin{array}{l}\text { Difficulty balancing work with } \\
\text { children }\end{array}$ & $\begin{array}{l}\text { Too many intellectual or work } \\
\text { requirements }\end{array}$ & $\begin{array}{c}\text { When I earn less than I think } \\
\text { I should }\end{array}$ \\
\hline
\end{tabular}

Table 2: Summary of Oppressive Situations 
Levels of Consciousness of Oppression

Using the analysis of the data from the interviews, I then worked with the group members and from this work there emerged a model showing six levels of awareness of oppression, as illustrated in Figure 1. Readers will see that this is similar to the treatment levels identified by Schiff (1975) within the discount matrix, with the significant addition of the need for contact with others. Within the groups, the participants used this model to analyse and understand their own processes of women's liberation.

\section{Other Findings}

The data collected showed the result of a dynamic and dialectic process being revealed by reality and which, quite inevitably, passed through the sieve of the criticisms of the group participants and was shared with objectivity, conviction and fairness.

The analysis made evident the relationship between current external oppressive situations and the internal oppressive situations, thus characterizing a continuum of the decoding of the superstructure of the individual (Question 1). This aspect was observed in both groups despite the difference between their cultural and socioeconomic levels.

In both groups, the situations identified as oppressive, which were directly related to the sexual discrimination at work, accounted for approximately $17 \%$ of all oppressive situations reported in each group. In Group One, approximately $56 \%$ of the situations identified as oppressive could be directly related to a feeling of inability to act due to being a woman. (for example: "at business, to make a deal or to stand up"). This is a feeling linked to the stereotypes of common sense, identified with the "gender" category, according to study by Lamas (1986). In Group Two (higher socioeconomic bracket) the situations related to the same feeling of inability account for approximately $40 \%$ of the total situations referred to in this group.

Approximately $28 \%$ of the situations referred to as being oppressive by Group One are directly related to these women's low socioeconomic bracket (for example: "to be in need of money and other resources"). Around $40 \%$ of the situations identified as oppressive by Group Two were directly related to discrimination against women at work (for example: "my ideas being used by other people, specially men, as if they were their own ideas"). These data, in addition to the fact that all women in Group Two were involved in specialized activities and earned money for their work, leads to the assumption that the insertion of women in the world of work shows to these women the extent of their discrimination. In Group One $50 \%$ of all women did not earn any money for their work at their own homes and therefore they remained more isolated (Gorz, 1982). The type of activity, together with these women's different insertion in the work world, make the inequality of opportunities for women of different social classes evident. (Goldsmith, 1986).

The answers to question 20 of the interview Schedule are also noteworthy. When asked if they talked to other women about oppressive situations felt by them at their work, only one woman in each group mentioned doing this frequently. One mentioned that she began to talk to other women after she understood the necessity of cooperative contact to liberate herself from the oppressive situation. Others answered that they never or almost never talked to other women about these situations outside the psychotherapeutic group. This characterises a high degree of alienation in relation to the importance of contact for liberation.

\section{Discussion}

The reverse of alienation means being powerful in this world. The task we set ourselves is to help us claim our alienated powers back. To be powerful in this world, you have to walk a road which goes through establishing contact in order to end isolation, developing awareness to end mystification, and taking action to end oppression. The awareness raising, especially the understanding of how oppressive influences operate in order to diminish our power, is the key to developing it. The development of awareness is the gathering of information about the world and how it works, and it is an important never-ending task to expand personal power in the world.

In this spiral of evolution, once in contact, each awareness that produces action with a liberating effect paves the way for a new opportunity, an opportunity to become de-alienated at a more complex level for a better understanding of the world. Each oppressive situation identified seems to make room for the identification of other oppressive, more abstract, and therefore subtler and more comprehensive situations. Likewise, liberation from an oppressive situation, that is $6^{\text {th }}$ level, seems to recover the belief in one's personal power to overcome other oppressive situations, and to do this with increasing speed and intensity.

\section{Limitations}

An obvious question about this research is whether it is still valid after so many years. Bastianelli (2014), in describing work done by Italian volunteers in Brazil each year since 2008, comments that "This is a land where children disappear and become victims of organ trafficking or sexual abuse, where fathers are out getting drunk and mothers wash the clothes of 
6th level - awareness of the situation, associated with contact, action that rescues the power for liberation.

$5^{\text {th }}$ level - awareness of an oppressive situation, awareness of the cause of this oppression, awareness of the possibility to change, awareness of potential personal power to change the situation; a lack of awareness of the importance of contact for liberation.

$4^{\text {th }}$ level - awareness of an oppressive situation, awareness of the cause of this oppression, awareness of the possibility to change, a lack of awareness of potential personal power to change the situation.

$3^{\text {rd }}$ level - awareness of an oppressive situation, awareness of the cause of this oppression, a lack of awareness of the possibility to change.

Once there is consciousness of the oppression, the liberation requires both contact and anger (that promotes motivation); it is the contact with other human beings that, when united, will mobilize against oppression. However, awareness and contact cannot produce liberation. This will only happen under some form of action. Only action taken by groups of people that feel anger due to the form in which they have been oppressed may lead to liberation.

At this moment, when there is awareness of the potential personal power to change, therapeutic contact and cooperative contact with other people are still needed to create a favourable (appropriate) and secure environment that stimulates a person to act to liberate the initial motivation (this action represents the overcoming of the script and the liberation of autonomy).

In this level, when there is awareness of the possibility to change (which to the child would mean disobeying Dad, by breaking the rules), the person may try to avoid the awareness of his/her self-competence to change, because of the fear of reliving the catastrophic experience and because this person expects to find a hostile and oppressive environment.

At this moment, when there is awareness of the oppression (discomfort by repetition), awareness of the cause (that would be: "Dad doesn't like it"), the person tries to avoid the awareness of the possibility to change, because this would put him/her in contact with the catastrophic experience involved in that situation of an early decision in the script and the fear of reliving it.

At the second level, there is growing awareness of the beliefs

$2^{\text {nd }}$ level - awareness of an oppressive that justify repetition. At this moment the person avoids contact with injunctions of the script, very much like a child who repeats "I shouldn't do this" while avoiding the contact with "Dad doesn't like it" or "Dad doesn't like me when I do this".

At this level, oppressive situations of the life script are reproduced without awareness of the discomfort produced by this. It is the moment of alienated repetitions, where the psychological games seem to be a more viable form of social relationship, or the most viable one. Rackets seem to be the way to feel, think and act. When the facilitator works with someone in this way, the facilitator knows that this person will soon experience the discomfort caused by the awareness of the repetition associated with the lack of awareness of the cause of this oppression.

Figure 1: Levels of Consciousness of Oppression 
fazendeiros (owners of large plantations) for a handful of beans. It seemed incredible to us, but slavery was prohibited in Maranhão only some decades ago, and some forms of slave labor still survive, even if the government fights them." (p. 88). I invite the reader to consider where else in the world the male/female stereotypes still exist, and how similar problems of oppression also affect men. In the UK the Government are currently running television advertisements asking the public to watch out for, and report, signs of human slavery that is now occurring there with men and women. (Hay, 2014).

There is also the way in which oppression was assumed to exist; the questions were worded with the implication that participants would be able to provide examples of oppression. This may have led to group members providing responses in order to 'please' the psychotherapist.

The further possible limitation that the researcher was also the psychotherapist is implicit in the nature of participatory action research. In this case, the aims of the research were identical to those of the psychotherapist, in that the intended outcomes were to increase the self-awareness and social consciousness of the participants in order that they might become more autonomous.

The research was conducted in Brazil and the examples of oppression experienced by participants may well be different within different cultures. Furthermore, no definition of oppression was provided to participants and that also may be defined differently by different groups, and different researchers.

The number of participants was small and it may well be that different examples would be identified if a larger group were interviewed. Similarly, there were only two groups that worked on the model of the Levels of Consciousness and other groups might have analysed the data differently.

\section{Conclusion}

The possibility of collective therapeutic work influencing the liberation of women so that they can bring about superstructural change is related to the difference in each woman's personal process, which characterizes their own liberation and its specificities, their choices and their status as unique individuals. It is possible to notice that the degree of awareness raising depends on these women's views on work and their action when working collectively. However, the expansion of spaces for perception and action by these women was more evident in Group One and subtler in Group Two.
In the first group, all these women began to participate more often in community groups, also exerting leadership. The changes that the women in the second group referred to and noticed seemed to appear on an individual level. However, there was no liberation in the sense of cooperative contact amongst equals in order to intensify action and raise the conscience of work groups in the wider population. It is possible that, through alienation on a particular level, women come to realize only theoretically the social determination of their behaviour, without capturing this fact in concrete everyday relations. This is particularly true for Group Two.

It is also possible that these women, in their process of overcoming oppression, stimulate other people's change by questioning and acting on their everyday relationships at work and their subsequent greater participation in groups. This transformation of oppressive situations when it comes to previously alienated and deterministic relationships, characterizes the possibility for action on the superstructure level.

It is hoped that, by presenting these findings, the model of the levels of awareness of oppression may provide a vehicle for use by other groups and individuals in their journey towards increased awareness of the dynamics of oppression and development of their own social consciousness.

Finally, we need to consider the dynamic relationship in which the overcoming of an oppressive situation means a new world and personal view. This, on a wider level, generates new oppressions to be overcome.

As this research was a process investigation, it does not end like an experiment. It highlights considerations about the process of de-alienation in which those women became involved. It points at new directions for joint reflection and action. These are meant to formulate a critical awareness of women's participation as individuals, as a gender and as participants in society as a whole.

\section{References}

Baratta, Giorgio (2001) Escola, filosofia e cidadania no pensamento de Gramsci: exercícios de leitura (School, philosophy and citizenship in Gramsci's thought: reading exercises) Pro-Posições 21: 1

Bastianelli, Laura (2014) An Italian Team uses Transactional Analysis to help Children in Brazil Transactional Analysis Journal 44:1 87-95

Berne, Eric (1974) Qué dice usted después de decir Hola? (What do you say after you say Hello?) Barcelona: Grijalbo. 
Campos, Leonard (2012) Cultivating Cultures of Courage with Transactional Analysis Transactional Analysis Journal 42: 3 209-219

Drego, Pearl (2006) Freedom and Responsibility: Social Empowerment and the Altruistic Model of Ego States Transactional Analysis Journal, 36: 2 90-104.

Drego, Pearl (2009) Bonding the ethnic child with the universal parent: Strategies and ethos of a transactional analysis eco-community activist Transactional Analysis Journal 39:3 193-206

Freire, Paulo (1979a) Educação e mudança. Rio de Janeiro. Paz e Terra.

Freire, Paulo (1979b) Conscientização. São Paulo. Cortez e Morais.

Goldsmith, Mary (1986) Debates antropológicos en torno a los estudios sobre la mujer. Nueva Antropologia, VIII: 30

Gorz, André (1982) Adeus ao proletariado: para além do socialismo. Rio de Janeiro: Forense-Universitária.

Gramsci, Antonio (1978) Cartas do cárcere. Rio de Janeiro: Civilização Brasileira.

Gramsci, Antonio (1982) Os intelectuais e a organização da cultura. Rio de Janeiro: Civilização Brasileira.

Hay, Julie (2014) personal communication

James M (1983) - Cultural script: Historical events vs historical interpretation Transactional Analysis Journal 13:4 217-223

Kabeer, N. (1994). Reversed realities, gender hierarchies in developmental thought. London: Verso.

Koshy, E, Koshy, V \& Waterman, H (2011) Action

Research in Healthcare London: Sage

Lamas, Marta (1986) La antropologia feminista y la categoria "genero". Nueva Antropologia, VIII: 30

Levin, Pamela (1977) Women's Oppression Transactional Analysis Journal 7:1 87-92

Levin, Pamela (2010) Eric Berne, “The 'Woman' Question," and Its Evolution in the TA World Transactional Analysis Journal 40:3 217-223
Mazzetti, Marco (2010) Eric Berne and Cultural Script Transactional Analysis Journal 40:3-4 187-195

Meyer, J (2000) Using qualitative methods in health related action research British Medical Journal 320178 181

Parkin, P (2009) Managing Change in Healthcare: Using Action Research London: Sage

Portelli, Hughes (1983) Gramsci e o bloco histórico. Rio de Janeiro: Paz e Terra.

Pozatti, Mauro L.; Pozatti, Jane M. C. (1980) Bases para a organização de uma comunidade na busca de melhores condições de vida - Experiência na Vila Augusta. Arq.

Med. Prev. (2):6-14.

Reisman, D (1950) The lonely crowd: A study of the changing American character New Haven: Yale University Press

Schiff, J (1975), Cathexis Reader: Transactional Analysis Treatment of Psychosis, New York: Harper \& Row Publishers Inc

Steiner, Claude (1975) ed. Readings in Radical Psychiatry. New York, Grove Press.

Steiner, Claude (1976) Os papéis que vivemos na vida. Rio de Janeiro: Artenova.

Strinatti, Dominic (1995) An Introduction to Theories of Popular Culture London: Routledge

Swantz, M L (2001) Introduction in Reason, P \& Bradbury, $\mathrm{H}$ The SAGE Handbook of Action Research London: Sage

Toledo, Regina, Lins, Vera, Winogron, Ana \& Mota, Clarice (1983) A dominação da mulher: os papéis sexuais na educação. 2nd edit. Rio de Janeiro: Vozes.

Whyte, W F (1991) Participatory Action Research Berkeley CA: Sage

Wyckoff, Hogie. (1976) Elaboração dos papéis sexuais dos homens e das mulheres. In Steiner, Claude ed. Os papéis que vivemos na vida. Rio de Janeiro: Artenova. Chapter 13, p. 160-170 


\section{Appendix 1: Structured Interview Schedule}

The structured interview was based on the following schedule, with 20 items arranged to pave the way to acknowledge the existing relationships between current external oppressive situations and intrapersonal alienation.

1) Remember three situations in which you feel oppressed at work.

2) Choose one.

3) What do you think and feel in this situation?

4) To what do you attribute this oppression?

5) What would you like to do in order to solve this oppression?

6) How would you feel if you had solved this oppression?

7) What do you usually do in this situation?

8) What do you feel when you deal with the situation the way you do today?

9) Choose two important people to you in your childhood (mother and father, if possible)

10) What would each one of them feel, think, say, if they saw you solve this oppression?

11) What does oppression mean to you?

12) Remember two situations in which you feel great at work.

13) Choose one.

14) What do think and feel in this situation?

15) To what do you attribute this well-being?

16) What do you usually feel and do after feeling like this?

17) What would those two important people to you feel, think, say, if they saw you in this situation of wellbeing?

18) Is all this information of use to you?

19) What can you do with this?

20) Do you talk to other women about these oppressive situations you feel at work? If not, why? If so, who with, where, how often, and what are these conversations for? 